\title{
Optimization of coiled tubing nozzle for sand removal from wellbore
}

\author{
Javed Akbar Khan ${ }^{1} \cdot$ Sonny Irawan ${ }^{2}$ Eswaran Padmanabhan ${ }^{1} \cdot$ Hussain H. Al-Kayiem ${ }^{3} \cdot$ Sahil Rai $^{2}$
}

Received: 20 August 2018 / Accepted: 11 June 2019 / Published online: 21 June 2019

(c) The Author(s) 2019

\begin{abstract}
Production is hampered by sand and scale that impede flow and require intervention. Although coiled tubing jetting tools have been very successful in wellbore cleaning operations, the coiled tubing unit has certain limitations and constraints. The fluid pumping pressures of fluids at the wellhead are limited to the normal pressure of pump, whereas some sand types and scales require a very high shear force to break and disintegrate. The dimensions of the coiled tubing unit nozzle size are directly related to the diameter of the production tubing. The present work consists in designing the nozzle of coiled tubing jetting tool with different dimensional parameters and analysing the design of the nozzle for required high outlet pressure, flow rate and velocity at various inlet pressures. Numerical technique was used to analyse the flow of fluid through the nozzle. The different port diameters and cone angles between 0.09 and 0.125 inch and $15^{\circ}$ and $45^{\circ}$, respectively, were simulated. The effects of these parameters on the outlet pressure, the mass flow at the outlet and the outlet velocities were predicted and analysed. Inner nozzle diameters smaller than 0.75 inch gave good results, and the 1 inch inner diameter gave lower performance. Therefore, the lower diameter nozzle provides better performance. Decreasing the number of ports from seven to five did not create a big difference in nozzle performance, as the seven ported nozzles provide slightly better performance.
\end{abstract}

Keywords Coiled tubing $(\mathrm{CT}) \cdot$ Nozzle design $\cdot$ Well clean-up $\cdot$ Sand $\cdot$ Fluid velocity/pressure

\section{Introduction}

Wellbore fill material is a major concern for operators around the world. This problem of production inhibition is commonly treated with coiled tubing (CT) interventions. However, as wells and completions become more complex and reserves are produced under increasingly harsh conditions, there are environments where conventional coiled tubing cleanout techniques do not allow effective removal of fill. Coiled tubing was once considered high risk and had few applications, but has now become an essential tool for well intervention (Afghoul et al. 1994). Modern CT equipment has many advantages over conventional methods of cleaning and reducing wellbore fill. These include mobile nature and

Javed Akbar Khan

javedkhan_niazi@yahoo.com

1 Institute of Hydrocarbon Recovery, Universiti Teknologi PETRONAS, 32610 Bandar Seri Iskandar, Malaysia

2 Petroleum Engineering Department, Universiti Teknologi PETRONAS, 32610 Bandar Seri Iskandar, Malaysia

3 Mechnical Engineering Department, Universiti Teknologi PETRONAS, 32610 Bandar Seri Iskandar, Malaysia lower cost operations, as there is no need to stop and connect the tubing joints, ability to withstand reasonably high loads, flexibility to work under high pressures in "live" wells without having to kill the well and the distinctive ability to pump fluids at all points irrespective of location in well and direction of motion (Afghoul et al. 1994). These capabilities are useful for wellbore cleaning operations as shown in Fig. 1.

Nowadays, many rotary jetting tools have appeared in the services operations. These tools have a longer length than conventional jetting tools because of the rotatory motor mounted with the nozzle. Rotational jetting tools have two major setbacks. First, the rotational speed of most of these rotating tools cannot be controlled. But for the tool to clean effectively, the cleaning head must rotate to a desired speed range during pre-planning of job and if this speed is different from this range, the pipe will not be properly cleaned (Connell et al. 2000a). Secondly, rotating tools depend on the starting angle of the fluid jet to create a rotation, such as a garden sprinkler (Connell et al. 2000b). The outlet torque is minimal (6-7 ft-lbf); therefore, the tool stalls easily when in contact with wall of the tubing or a bridge (Connell et al. 2000a). Bull nose jetting tools are widely used, specially, with a coiled tubing unit in the oil and gas 

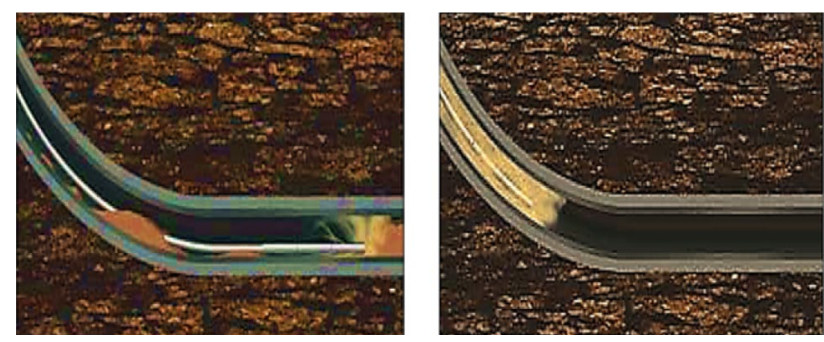

Fig. 1 Sand removal procedure (Ali et al. 2004)

industry to remove scales, sand and other materials hampering production. A bull nose jetting tool has a non-rotating high-pressure jetting nozzle. It is widely used because it can provide a complete radial coverage of the tubing and also the porting can be performed in a wide range of combinations such as up, down and side jetting. These nozzles are of various dimensions, made of different materials and have different pressures.

Scale build-up significantly reduces the rate of production. Scale accumulation is a worldwide services problem, but the composition and characteristics of the scale can be very different in different places. As a result, most of the tools used to remove the scale are not efficient enough. Many slow rotating and non-rotating jetting tools have shown effective cleaning of the wellbore and make the CT jetting tool a commonly used scale-removing tool (Connell et al. 2000a). The most common method to remove sand is to pass the CT over the fill and then increase the flow that begins to penetrate into the fill ( $\mathrm{Li}$ et al. 2008). But in many cases, the nozzle and the jetting tool were sandwiched between two layers of sand, as the broken sand accumulates just behind the jetting tool. As a result, cleanout performed by slow continuous penetration into the fill followed by a stationary circulation followed by a moving of the CT upwards over the previous penetration interval, and continuous circulation while running back in the hole is used and found to be very efficient (Li and Green 2011). The wellbore cleaning process depends on several variables, including fluid properties, flow velocities, well geometry, deviation, particle properties, penetration rate and so on. CT strings are available in different sizes. However, 1.25/2.375" tubing, 1/2" tubing, 1" and 0.75/1.5" tubing are the most common (Li et al. 2010).

The accumulation of sand in the wellbore is mainly caused by the leakage of perforation packing; therefore, study has been carried out to evaluate the influence of fine particles composition on optimal design of sand control in offshore oilfield (Deng et al. 2013). Numerical analysis of a sand production test on a perforated cylindrical specimen is performed to predict sand accumulation (Mohamad-Hussein and Ni 2018). Experimental and numerical studies on the effect of fluid viscosity, velocity and hole inclination on cutting transport in horizontal and highly deviated wells have
Table 1 Dimensions of the selected catalogue nozzle (Gardner 2018)

\begin{tabular}{ll}
\hline Dimensions & Values \\
\hline Outer diameter & $0.687^{\prime \prime}$ \\
Length & $1.562^{\prime \prime}$ \\
Threading & $9 / 16^{\prime \prime} \mathrm{HP}$ \\
Port pattern & $1 \times 0.089^{\prime \prime}-\mathrm{A}$ \\
& $4 \times 0.089^{\prime \prime}-\mathrm{C}\left(90^{\circ}\right)$ \\
\hline
\end{tabular}

been carried out (Piroozian et al. 2012; Zakerian et al. 2018). Well clean-up operation is performed to remove accumulated sand with brine when the bottom hole pressure is high, while clean-up operation is effective with foam when the bottom hole pressure is low, as studied in the past (Khan and Pao 2013; Pao and Khan 2014; Pao et al. 2015).

The pumping pressure of the fluids at the wellhead is limited to the normal pressure of the pump, while certain types and sand require a very high pressure to break and disintegrate. Therefore, the design should help to increase the pressure tremendously. The dimensions of the coiled tubing unit, including the size of the nozzle, are directly related to the diameter of the production tubing. Larger nozzles would lead to stuck in pipe and cause a lot of damage and hindrance, while smaller nozzles would not be able to produce the amount of kinetic energy required to break/remove these wellbore fill materials. Therefore, the design must be appropriate and applicable to different pipe diameters. The objectives are to design a coiled tubing jetting tool nozzle for well cleaning operations and to analyse the design for the required outlet pressure, flow rate and velocity at different inlet pressures.

\section{Methodology}

For the purpose of data collection, many research papers and product catalogues were referred. Such nozzle designs are of utmost importance to the manufacturing company and are therefore not shared in their catalogues. Gardner Denver Jetting Systems, Inc., a high-pressure nozzle manufacturing company, shared a base design and performance analysis of the different nozzles. The dimensions of the nozzle are given in Table 1.

As can be seen in Table 1, this nozzle has a 9/16" female thread with a port at $0^{\circ}$ and the rest four at $90^{\circ}$ each. The port diameter is $0.089^{\prime \prime}$ and the nozzle OD is $0.687 "$. The total length of this nozzle is about 1.562". The outer/internal geometry of this nozzle is illustrated in Fig. 2.

The catalogue data used as parameters to validate the design are the pressure drop along the nozzle and the mass flow rates at the outlet at different pressures. Table 2 shows the parameters. 


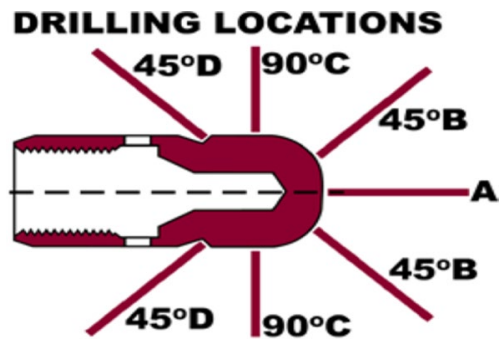

Fig. 2 Original and schematic diagram of the selected catalogue nozzle (Gardner 2018)

Table 2 Given catalogue performance analysis data (Gardner 2018)

\begin{tabular}{lll}
\hline Dimension & Mass flow rate (GPM) & Pressure drop (PSI) \\
\hline 9/16" OD $\times 0.156 "$ & 5 & 850 \\
Wall - 40 kPSI & 10 & 3200 \\
& 20 & $>10,000$ \\
Orifice dia. & Pressure (PSI) & Mass flow rate (GPM) \\
$0.089 "$ & 2000 & 10.247 \\
& 2500 & 11.456 \\
& 3000 & 12.550 \\
& 3500 & 13.555 \\
& 4000 & 14.491 \\
\hline
\end{tabular}

As can be seen in Table 2, the pressure drops along the nozzle at inlet flow rates of five, ten and twenty gallons per minute (GPM) in the range of $800-15,000$ psi. Outlet mass flow rates range from 10 to 18 GPM at an inlet pressure of 2000-6000 psi. In order to validate the design of this nozzle, a bull nose jetting nozzle with button tips is used. CATIA software was used to design this nozzle. ANSYS Workbench 15.0 was used to analyse the fluid flow through the nozzle. The pressure drops along the nozzle at different flow rates and also the flow rates at different pressures were computed from the simulation. In Fig. 3, it is clearly indicated that four of the five ports are at $90^{\circ}$ and one port is at $0^{\circ}$. This nozzle contains seven ports in total: one port in the centre, with an angle of $0^{\circ}$, while the other six ports at $60^{\circ}$ angle to the central axis.

Meshing was done on the designed nozzle using the ANSYS fluent software as shown in Fig. 4. The meshing resulted in the following: number of nodes 62454 and number of elements 332654. Mesh generation is one of the most crucial aspects of design simulation. It basically divides the whole design into small units. All the iterations/calculations are carried out on each of these cells/ units, therefore giving a real/dynamic result. The meshing should be done in such a way that the number of cells should not be very high/low. The internal parts, i.e. the surface of the design through which the fluid flows, should have more of such cells. More cells at these areas make it more sensitive to the fluid flow, and therefore the results become more accurate. In the above figure, the cross section reveals that the cells on the internal body are larger in number when compared to the outer body which is a good sign. Also, the cells should preferably be rectangular and similar in shape/size. Looking at the outer body of the mesh in the above figure, it is clear that the cells are similar in size/shape and are uniformly distributed.

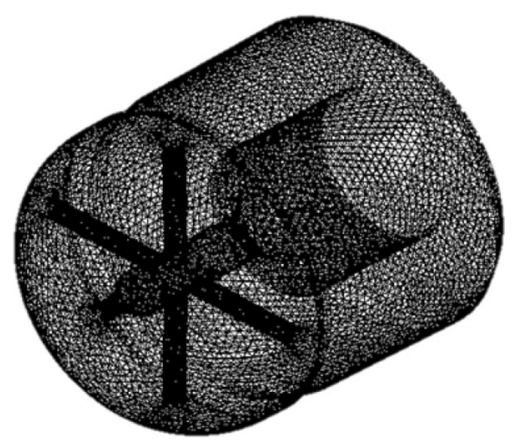

Fig. 4 Meshing of the nozzle design from different cross sections

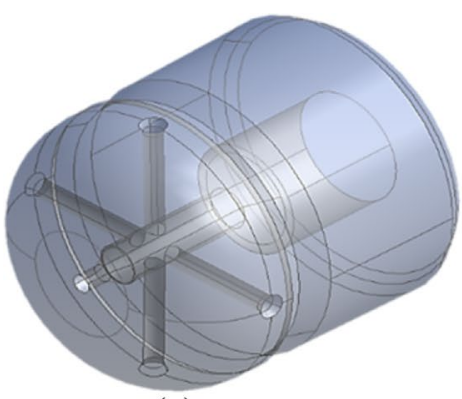

(a)

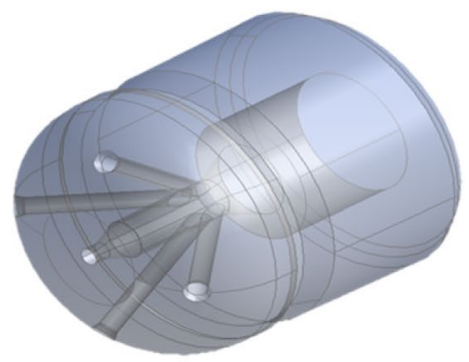

(b)

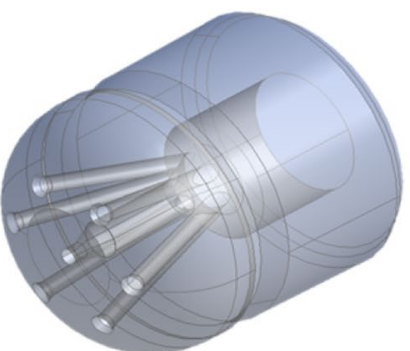

(c)

Fig. 3 CATIA design of the selected nozzle; a nozzle with 1 port@ $0^{\circ} \_4$ ports@9 $90^{\circ}$ design configurations, b nozzle with 1 port@ $0^{\circ} \_4$ ports@45 ${ }^{\circ}$ design configurations, c nozzle with 1port@ $0^{\circ} \_6$ ports@30․ design configurations 


\section{Numerical model}

For an inviscid flow, ANSYS FLUENT solves the Euler equations. The equation for continuity and momentum can be written as shown in Eqs. 1 and 2:

$\nabla \cdot(\rho U)=0$

$\nabla \cdot(\rho U \times U)=-\nabla p+\nabla \cdot \tau+S_{M}$,

where stress tensor $(\tau)$ is associated with the strain rate by

$\tau=\mu\left(\nabla U+(\nabla U)^{\tau}-2 / 3 \delta \nabla \cdot U\right)$.

Total energy equation is as follows:

$\nabla \cdot\left(\rho U h_{\mathrm{tot}}\right)=\nabla \cdot(\lambda \nabla T)+\nabla \cdot(U \cdot \tau)+U \cdot S_{M}+S_{E}$,

where $h_{\text {tot }}$ is referred to total enthalpy and $\nabla \cdot(U \cdot \tau)$ is named viscous work term and denotes viscous stresses. The term $U \cdot S_{M}$ was neglected in simulation as it represents work because of external momentum transfer.

\section{Parameters}

After the validation is successful, certain dimensional and physical properties of the nozzle are altered and then they are analysed. The optimum results are recorded and subsequently a selection is made. The various dimensional alterations made are displayed in Fig. 5 and Table 3.

Five different parameters as shown in Table 3 with each having three unique values are selected. Therefore, a total of 243 different configurations were generated and analysed.

\section{Validation of numerical model}

The nozzle was designed using the CATIA designing software; all the dimensions given in the catalogue (Table 1) were followed. In the validation of the design, we compare

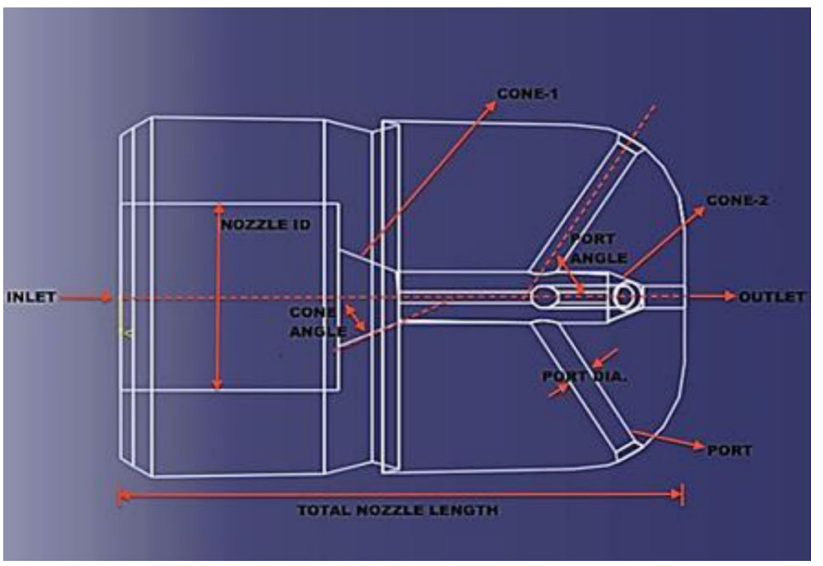

Fig. 5 Components of the nozzle
Table 3 Parameters used to set up various design configurations

\begin{tabular}{ll}
\hline Parameter & Values \\
\hline Diameter of nozzle port & $0.09^{\prime \prime}$ \\
& $0.125^{\prime \prime}$ \\
& $0.155^{\prime \prime}$ \\
Cone angle & $45^{\circ}$ \\
& $30^{\circ}$ \\
& $15^{\circ}$ \\
Nozzle inner diameter & $0.65625^{\prime \prime}$ \\
& $0.75^{\prime \prime}$ \\
& $1^{\prime \prime}$ \\
Nozzle lengths & $1.562 \times 1.35(0.6) ”$ \\
[Total Length $\times 1$ st Cone & $2.125 \times 1.836(0.82) ”$ \\
Length (2nd Cone Length)] & $3.125 \times 2.7(1.2) ”$ \\
Number/location of ports & 1 port@ $0^{\circ}+4$ ports $@ 90^{\circ}$ \\
& 1 port@ $0^{\circ}+6$ ports@ $30^{\circ}$ \\
& 1 port@ $0^{\circ}+4$ ports@ $45^{\circ}$ \\
\hline
\end{tabular}

our analysis with the given values (Table 2). The various parameters of comparison are the flow rate at the outlet and the pressure difference along the nozzle.

\section{Pressure drop validation}

In Table 4, the given pressure drop values in the catalogue at various mass flow rate at inlet are nearly equal, which ratifies the design in Fig. 2.

The contour in Fig. 6 shows the effects of fluid flow on pressure inside the nozzle at 5 GPM mass flow rate at the inlet. The colours at the outlet are orange/red and at the inlet are mostly yellow/turmeric, therefore giving us a fare idea about the difference in pressure ( $~ 850$ PSI).

Examining such contours for all the three given values of inlet flow rate generates pressure drops almost identical to the values stated in the catalogue. The plot in Fig. 7 exhibits the close proximity of the simulated results to the ones given in the catalogue.

Table 4 Comparison of simulated pressure drop values with given values in the catalogue, 9/16" OD $\times 0.156$ " Wall - 40K PSI

\begin{tabular}{|c|c|c|}
\hline Mass flow rate, GPM & $\begin{array}{l}\text { Pressure drop, psi (litera- } \\
\text { ture) }\end{array}$ & $\begin{array}{l}\text { Pressure drop, } \\
\text { psi (simulated) }\end{array}$ \\
\hline 5 & 850 & 850 \\
\hline 10 & 3200 & 3500 \\
\hline 20 & $>10,000$ & 13,500 \\
\hline
\end{tabular}


Fig. 6 Pressure contour for the nozzle at 5 GPM inlet mass flow rate

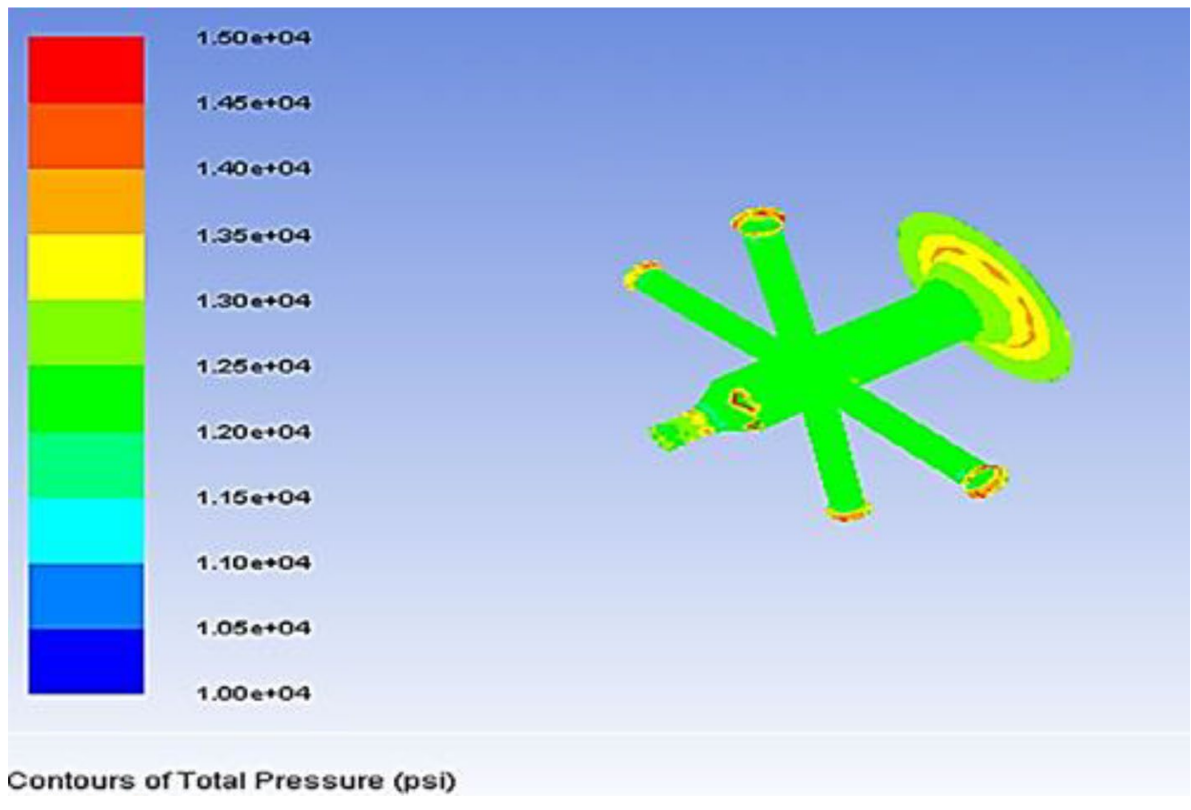

Fig. 7 Pressure drop versus flow rate plot to compare the given and simulated values

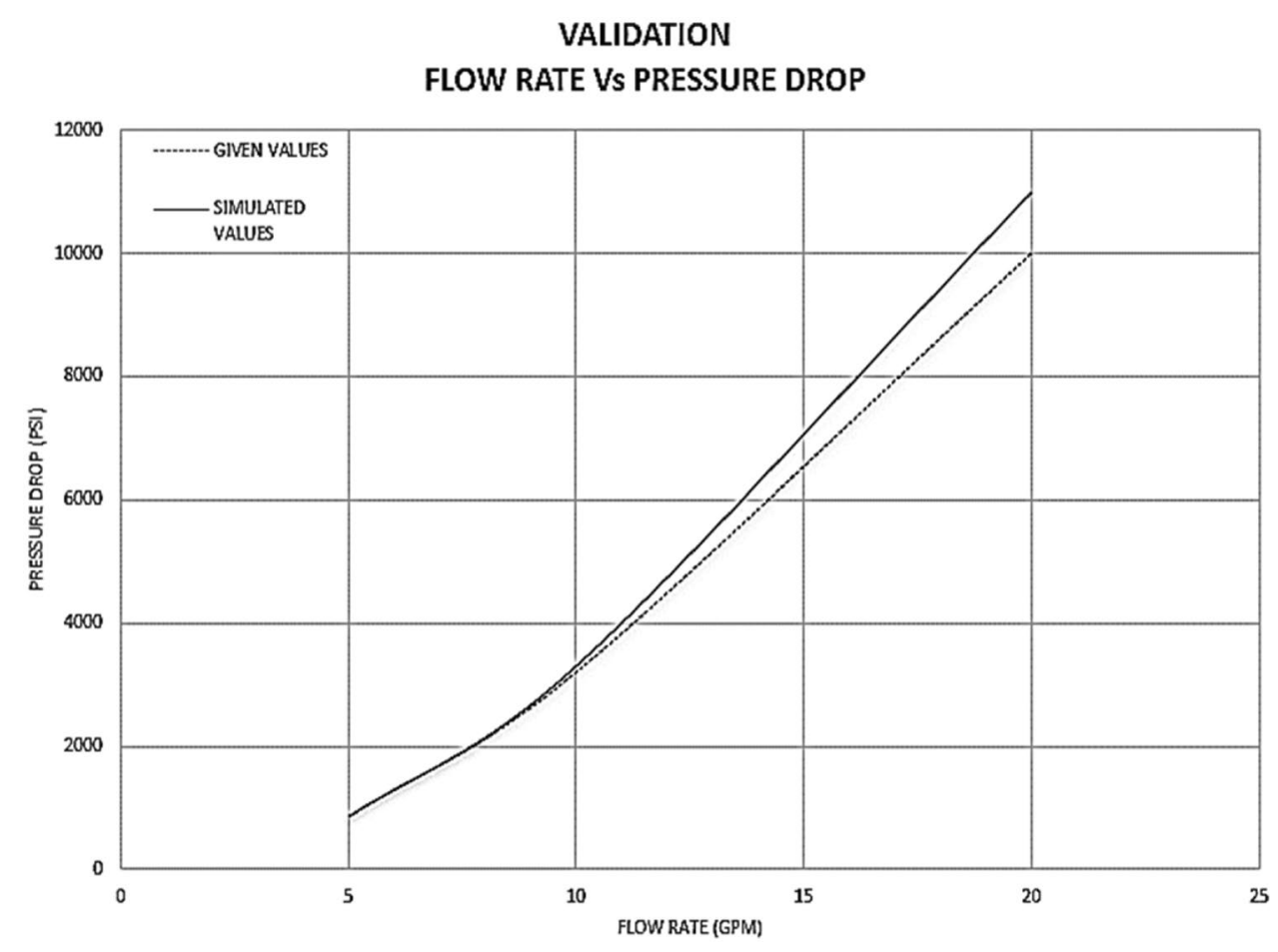

\section{Results and discussion}

Effect of different port diameter and cone angle at various conditions was calculated to evaluate the optimum design for higher pressure at outlet.

\section{Effects of different port diameters and cone angles}

The various port diameters which are analysed are $0.09 \mathrm{inch}$, $0.125 \mathrm{inch}$ and $0.155 \mathrm{inch}$. The cone angles used are $45^{\circ}, 30^{\circ}$ and $15^{\circ}$. The effects of these parameters on the outlet pressure, outlet mass flow rate and outlet velocities are studied for all the three design configurations. 


\section{Outlet pressure comparison}

Figure 8 shows the plot to compact the results for all the nozzle configurations (i.e.1port@0 $0^{\circ} 6$ ports@30 1port@0﹎4ports@90, 1port@0﹎4ports@45) with port diameter on the $x$-axis, the outlet pressure on the $y$-axis and the cone angle on the secondary $y$-axis. The yellowcoloured line indicates the cone angle, and the grey, orange and blue plot lines differentiate between the different port angles, i.e. $30^{\circ}, 90^{\circ}$ and $45^{\circ}$. After observing the results, it is noted that at the highest port diameter of 0.155 inch the pressure at the outlet is the highest, whereas the outlet pressures are in the same range in the lower 0.125 inch and 0.009 inch port diameters. Cone angle of $45^{\circ}$ gives the best pressure results at the outlet. Cone angle of $30^{\circ}$ gave intermediate results. Low pressure at outlets is recorded at a cone angle of $15^{\circ}$. Therefore, as we increase the cone angle the outlet pressure increases. Looking at the nozzle performances, 1port@0 $0^{\circ}$ 6ports@30 configuration performs exceedingly well and gives the highest pressures at outlet followed by 1port@0_4ports@90configuration, and 1port@0 $0^{\circ} 4$ ports@45 configuration records the lowest outlet pressures.

Table 5 shows the evaluation of various combinations of design for obtaining the required outlet pressure at various inlet pressures. Analysis of different designs shows that optimum pressure is obtained for a 0.155 inch port diameter, $45^{\circ}$ cone angle and $30^{\circ}$ port angle, while the performance of the nozzle decreases with a port diameter of 0.009 inch, a cone angle of $15^{\circ}$ and a port angle of $45^{\circ}$. As the port angle increases to $90^{\circ}$, the port diameter of 0.125 inch and the cone angle of $30^{\circ}$ cause an intermediate upsurge in the outlet pressure.

\section{Outlet velocity comparison}

Figure 9 shows the plot for all the nozzle configurations (i.e.1port@0 $0{ }^{\circ} 6$ ports@30,1port@0 0 _4ports@90ªnd 1port@0 $0^{\circ} 4$ ports@45 $)$ with port diameter on the $x$-axis, the outlet velocity on the $y$-axis and the cone angle on the secondary $y$-axis. The yellow-coloured line indicates the cone angle, and the grey, orange and blue plot lines differentiate between the different port angles, i.e. $30^{\circ}, 90^{\circ}$ and

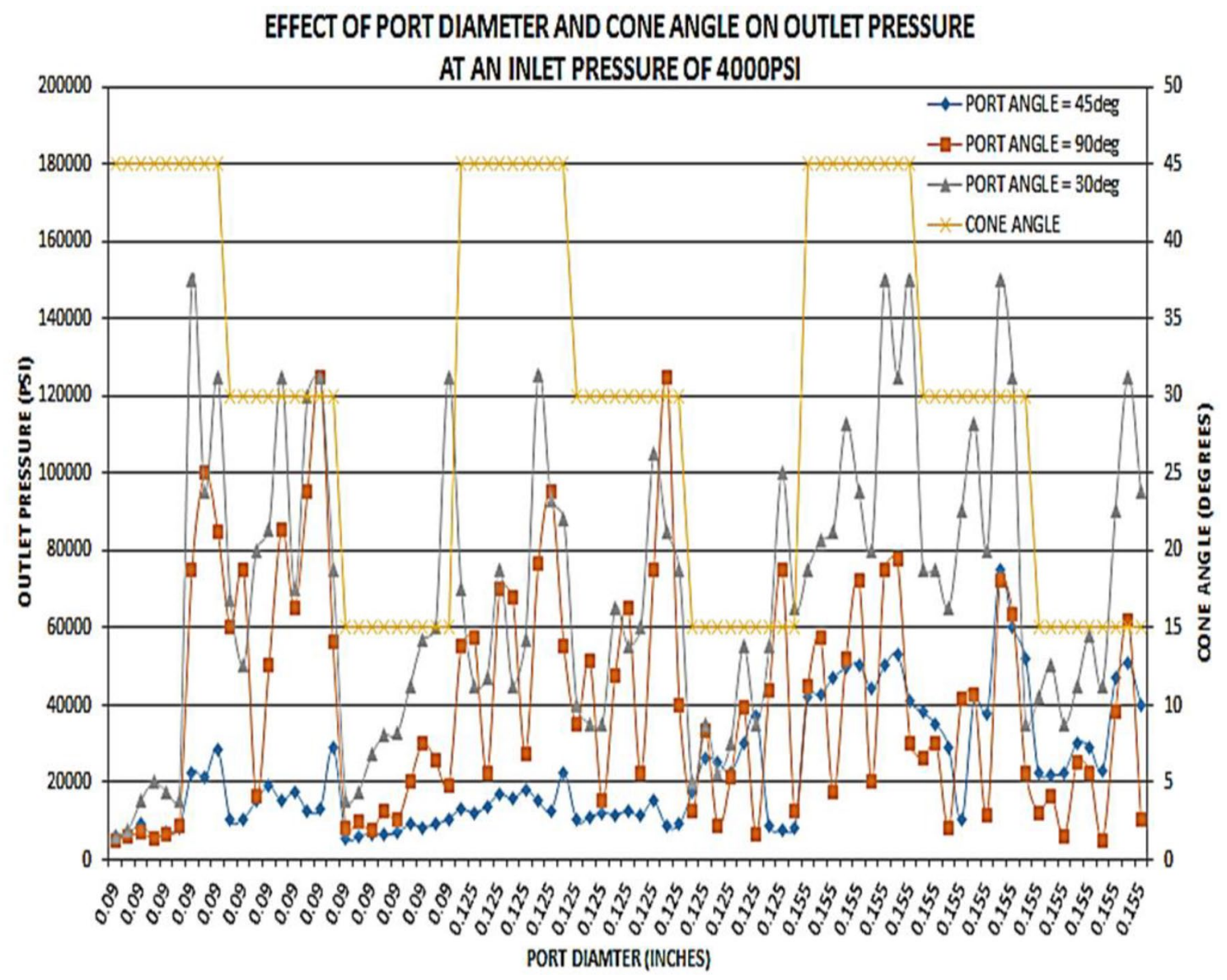

Fig. 8 Effect of port diameter and cone angle on outlet pressure at an inlet pressure of 4000 PSI 
Table 5 Effects of port diameter, cone angle and port angle on outlet pressure

\begin{tabular}{|c|c|c|c|}
\hline \multirow{2}{*}{$\begin{array}{l}\text { Factors effecting outlet } \\
\text { pressure }\end{array}$} & \multicolumn{3}{|l|}{ Inlet pressure } \\
\hline & 4000 PSI & 5000 PSI & 8000 PSI \\
\hline \multirow[t]{3}{*}{ Port diameter } & $0.155^{\prime \prime}:$ High & $0.155^{\prime \prime}:$ High & $0.155^{\prime \prime}$ Intermediate \\
\hline & $0.125^{\prime \prime}:$ Intermediate & $0.125^{\prime \prime}$ Intermediate & $0.125 "$ : Intermediate \\
\hline & 0.009": Low & 0.009": Low & 0.009": High \\
\hline \multirow[t]{3}{*}{ Cone angle } & $45^{\circ}:$ High & $45^{\circ}:$ High & $45^{\circ}:$ High \\
\hline & $30^{\circ}$ : Intermediate & $30^{\circ}:$ Intermediate & $30^{\circ}:$ Intermediate \\
\hline & $15^{\circ}:$ Low & $15^{\circ}:$ Low & $15^{\circ}:$ Low \\
\hline \multirow[t]{3}{*}{ Port angle } & $30^{\circ}:$ High & $30^{\circ}:$ High & $30^{\circ}:$ High \\
\hline & $45^{\circ}:$ Low & $45^{\circ}:$ Low & $45^{\circ}:$ Low \\
\hline & $90^{\circ}:$ Intermediate & $90^{\circ}:$ Intermediate & $90^{\circ}:$ Intermediate \\
\hline
\end{tabular}

EFFECT OF PORT DIAMETER AND CONEANGLE ON OUTLET VELOCITY AT ANINLET PRESSURE OF 400OPSI

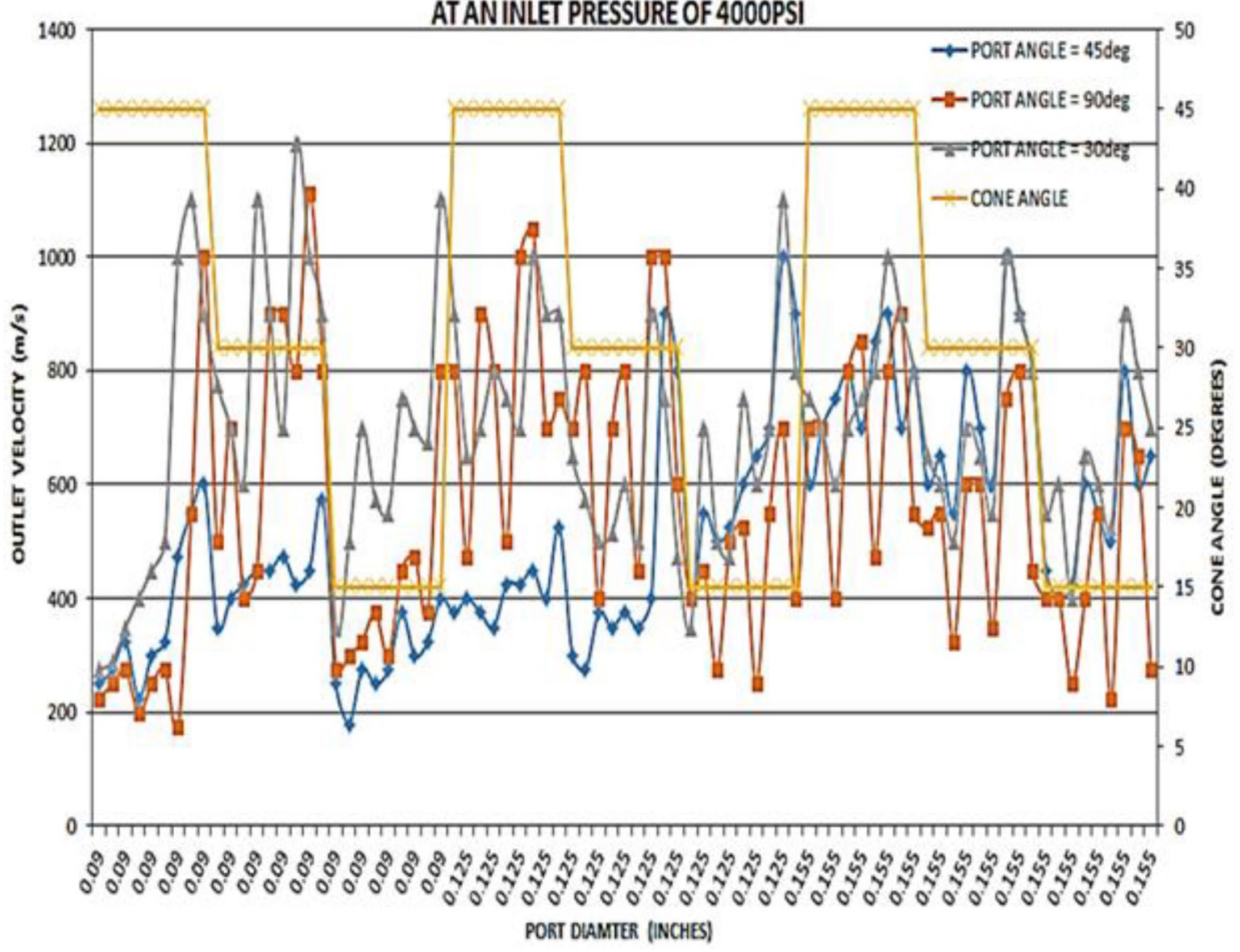

Fig. 9 Effect of port diameter and cone angle on outlet velocity at an inlet pressure of 4000 PSI

$45^{\circ}$. As can be seen that the outlet velocity decreases from 0.009 inch port diameter to 0.155 inch port diameter, nozzles with port angle of $45^{\circ}$ undergo an increase in velocity with an increase in the port diameter. But, on the whole there is a clear fall in the outlet velocity with an increase in the port diameter. Cone angle of $15^{\circ}$ records a low outlet velocity throughout, whereas the outlet velocities for $30^{\circ}$ and $45^{\circ}$ cone angles are in close approximation to each other. On an average, the nozzles with $60^{\circ}$ port angles give the highest velocities. The plot indicates that the outlet velocity for $60^{\circ}$ port angle decreases below the nozzles with $45^{\circ} / 90^{\circ}$ port angles as the port diameter increases from 0.125 to 0.155 inch. In totality, the 1port@ $0^{\circ}$ 6ports@30 configuration with an outlet velocity range of $1100-400 \mathrm{~m} / \mathrm{s}$ gives the best

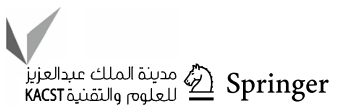


results, followed by 1 port@ $00^{\circ}$ 4ports@ $90^{\circ}$ configuration ranging from 1000 to $300 \mathrm{~m} / \mathrm{s}$, and a low $800-200 \mathrm{~m} / \mathrm{s}$ range is obtained for the 1 port @ $0^{\circ}$-4ports@ $45^{\circ}$ configuration.

There are some cases during fill removal where higher velocity is required rather than higher pressure. Table 6 shows the evaluation of various combinations of design for obtaining the required outlet velocity at $4000-8000$ psi pump pressure. Analysis of different designs shows that optimum velocity is obtained for a 0.009 inch port diameter, $30^{\circ}$ and $45^{\circ}$ cone angles and $30^{\circ}$ port angle, while the performance of the nozzle decreases with a port diameter of $0.155 \mathrm{inch}$, a cone angle of $15^{\circ}$ and port angles of $45^{\circ}$ and $90^{\circ}$.

\section{Outlet mass flow rate comparison}

Figure 10 shows the plot for all the nozzle configurations (i.e.1port@0 $0{ }^{\circ} 6$ ports@30 $0^{\circ}$ 1port@0 0 _4ports@90and 1port@0 $0^{\circ} 4$ ports@45 $)$ with the port diameter on the $x$-axis, the outlet mass flow rate on the $y$-axis and the cone angle on the secondary $y$-axis. The yellow-coloured line indicates the cone angle, and the grey, orange and blue plot lines differentiate between the different port angles, i.e. $30^{\circ}, 90^{\circ}$ and $45^{\circ}$.

There is an increase in the mass flow rate from about 50GPM to around 150GPM. This increment is due to the increase in port diameter from 0.009 to $0.155 \mathrm{inch}$. The larger the port area, the larger the volume flowing through it, which will increase the mass flow rate. Interestingly, the configuration 1port@0 $0^{\circ}$ 6ports@30 gives lower outlet flow rates (75-25 GPM) than the other two configurations. On an average, the highest flow rates are recorded by the nozzles with $90^{\circ}$ port angle ranging from 175 to $25 \mathrm{GPM}$, followed by the 1port@0 $0^{\circ}$ 4ports@ $45^{\circ}$ configuration ranging from 150 to $25 \mathrm{GPM}$. The cone angle of $45^{\circ}$ gives the highest outlet flow rate followed by $30^{\circ}$ and $15^{\circ}$, although cone angles of $45^{\circ}$ and $30^{\circ}$ have very close flow rate values. Once a large amount of fill material is accumulated in the wellbore, a higher mass flow is required to suspend that amount of material. Table 7 shows the evaluation of various combinations of design for obtaining the required outlet mass flow rate at various inlet pressures. Analysis of different designs shows that optimum mass flow rate is obtained for a 0.155 inch port diameter, $45^{\circ}$ cone angle and $30^{\circ}, 45^{\circ}$ and $90^{\circ}$ port angles.

\section{Effects of different nozzle inner diameters and total nozzle length}

Effect of various nozzle inner diameters ( 0.65 inch, 0.75 inch and $1 \mathrm{inch}$ ) is analysed. The total nozzle length is 1.562 inch, 2.125 inch and $3.125 \mathrm{inch}$. The effects of these parameters on the outlet pressure, outlet mass flow rate and outlet velocities are studied for all the three design configurations.

\section{Outlet pressure}

Figure 11 presents the results of outlet pressure at all nozzle configurations (i.e.1port@0 $0^{\circ}$ 6ports@30 1port@0 $0^{\circ} 4$ ports@90 and 1port@0 0 _4ports@45 $5^{\circ}$ with the total nozzle length (1.562 inch, 2.125 inch and 3.125 inch) on the $x$-axis, the outlet pressure on the $y$-axis and the nozzle inner diameter on the secondary $y$-axis. The yellowcoloured line indicates the nozzle inner diameter $(0.65 \mathrm{inch}$, 0.75 inch and 1 inch), and the grey, orange and blue plot lines differentiate between the different port angles, i.e. $30^{\circ}$, $90^{\circ}$ and $45^{\circ}$. Nozzles with port angle of $45^{\circ}$ do not give high outlet pressures at 4000 PSI inlet pressure. It is clear that the 1port@0 $0^{\circ} 6$ ports@30․ configuration achieves the highest outlet pressures out of the three, followed by nozzles with port angle of $90^{\circ}$. At a nozzle inner diameter of 1 inch, the pressure drops to a lower value, whereas as the nozzle ID decreases from 1 inch to 0.75 inch and 0.65 inch the outlet pressure rating increases. The outlet pressure values are evidently higher with smaller nozzle length of 1.562 inch, but there is a very less difference in the outlet pressure with $2.125 \mathrm{inch}$. The pressure recorded with 3.125 inch of nozzle length is the lowest, especially for nozzles with $45^{\circ}$ and $90^{\circ}$ port angles. The nozzle with $60^{\circ}$ port angle has the best performance throughout.
Table 6 Effects of port diameter, cone angle and port angle on outlet velocity

\begin{tabular}{llll}
\hline $\begin{array}{l}\text { Factors effecting outlet } \\
\text { velocity }\end{array}$ & Inlet pressure & & \\
\cline { 2 - 4 } & 4000 PSI & 5000 PSI & 8000 PSI \\
\hline Port diameter & $0.155^{\prime \prime}:$ Low & $0.155^{\prime \prime}:$ Low & $0.155^{\prime \prime}:$ Low \\
& $0.125^{\prime \prime}:$ Intermediate & $0.125^{\prime \prime}:$ Intermediate & $0.125^{\prime \prime}$ Intermediate \\
& $0.009^{\prime \prime}:$ High & $0.009^{\prime \prime}:$ High & $0.009^{\prime \prime}:$ High \\
Cone angle & $45^{\circ}:$ High & $45^{\circ}:$ High & $45^{\circ}:$ High \\
& $30^{\circ}:$ High & $30^{\circ}:$ High & $30^{\circ}:$ High \\
& $15^{\circ}:$ Low & $15^{\circ}:$ Low & $15^{\circ}:$ Low \\
Port angle & $30^{\circ}:$ High & $30^{\circ}:$ High & $30^{\circ}:$ High \\
& $45^{\circ}:$ Intermediate & $45^{\circ}:$ Intermediate & $45^{\circ}:$ Low \\
& $90^{\circ}:$ Intermediate & $90^{\circ}:$ Intermediate & $90^{\circ}:$ Intermediate \\
\hline
\end{tabular}




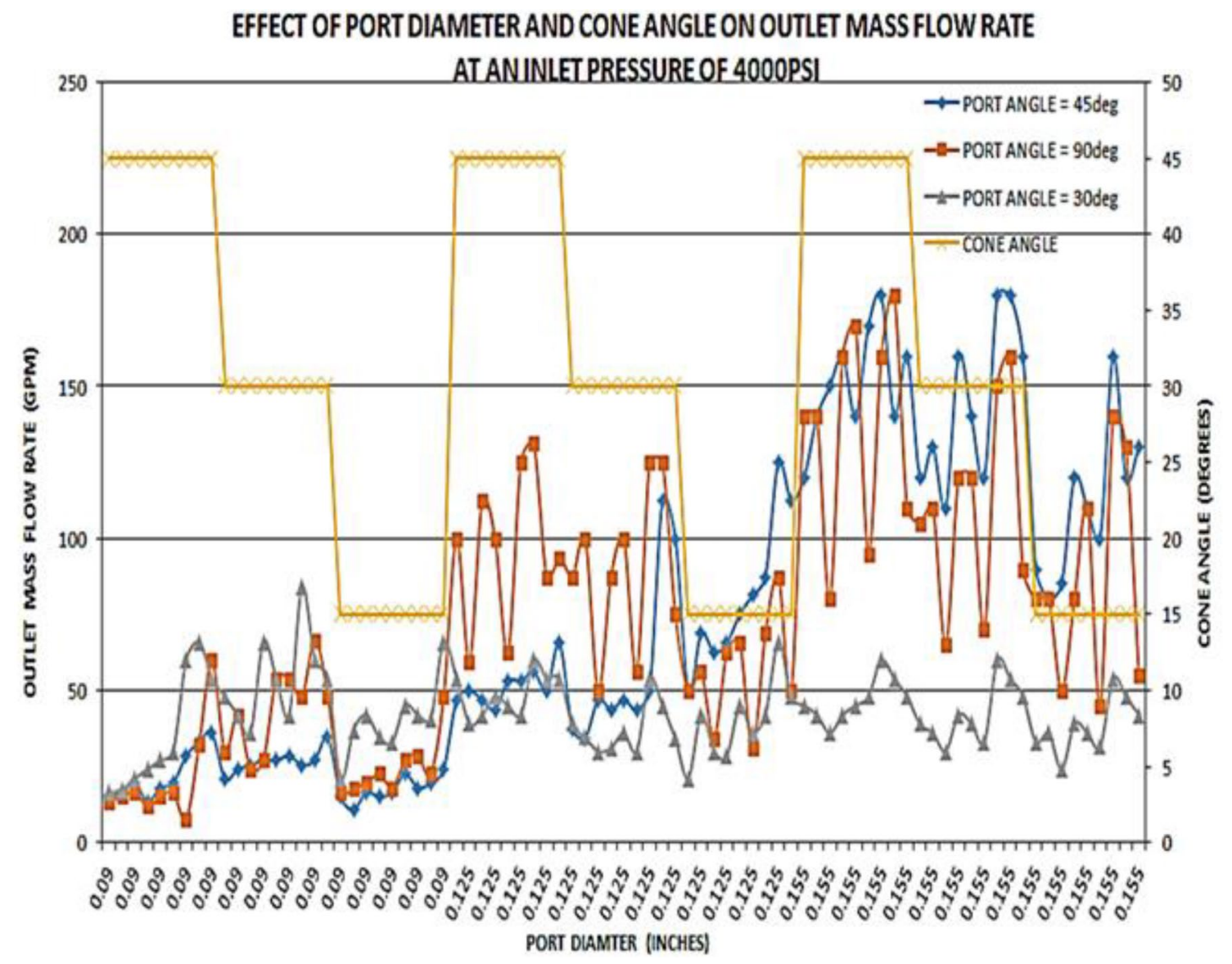

Fig. 10 Effect of port diameter and cone angle on outlet mass flow rate at an inlet pressure of 4000 PSI

Table 7 Effects of port diameter, cone angle and port angle on outlet mass flow rate

\begin{tabular}{llll}
\hline $\begin{array}{l}\text { Factors effecting outlet } \\
\text { mass flow rate }\end{array}$ & Inlet pressure & & \\
\cline { 2 - 4 } & 4000 PSI & 5000 PSI & 8000 PSI \\
\hline Port diameter & $0.155^{\prime \prime}:$ High & $0.155^{\prime \prime}:$ High & $0.155^{\prime \prime}:$ High \\
& $0.125^{\prime \prime}:$ Intermediate & $0.125^{\prime \prime}:$ Intermediate & $0.125^{\prime \prime}$ Intermediate \\
& $0.009^{\prime \prime}:$ Low & $0.009^{\prime \prime}:$ Low & $0.009^{\prime \prime}:$ Low \\
Cone angle & $45^{\circ}:$ High & $45^{\circ}:$ High & $45^{\circ}:$ High \\
& $30^{\circ}:$ Intermediate & $30^{\circ}:$ Intermediate & $30^{\circ}:$ Intermediate \\
& $15^{\circ}:$ Low & $15^{\circ}:$ Low & $15^{\circ}:$ Low \\
Port angle & $30^{\circ}:$ Low & $30^{\circ}:$ High & $30^{\circ}:$ High \\
& $45^{\circ}:$ High & $45^{\circ}:$ High & $45^{\circ}:$ High \\
& $90^{\circ}:$ High & $90^{\circ}:$ Intermediate & $90^{\circ}:$ Intermediate \\
\hline
\end{tabular}

As shown in Fig. 12, the high output pressures are achieved with a $60^{\circ}$ port angle followed by nozzles with an output angle of $90^{\circ}$, with $45^{\circ}$ port-oriented nozzles giving low pressure values at the output. The 1 -inch ID nozzle gives low output pressures, while 0.625 -inch ID nozzle gives a high dominant output pressure rating. The nozzle length of 1.562 inch gives the highest pressures at the outlet and is clearly represented on the graph. It is followed by a nozzle length of 2.125 inch, and the lowest values are reached by a nozzle length of $3.125 \mathrm{inch}$. This clarifies that the nozzles with a small nozzle length and the diameter of the nozzle with an orifice angle of $30^{\circ}$ give the best nominal pressure at the outlet. Table 8 shows the evaluation of various combinations of design for obtaining the required outlet pressure by varying total nozzle length, nozzle ID and port angle at 4000-8000 psi pump pressure. 


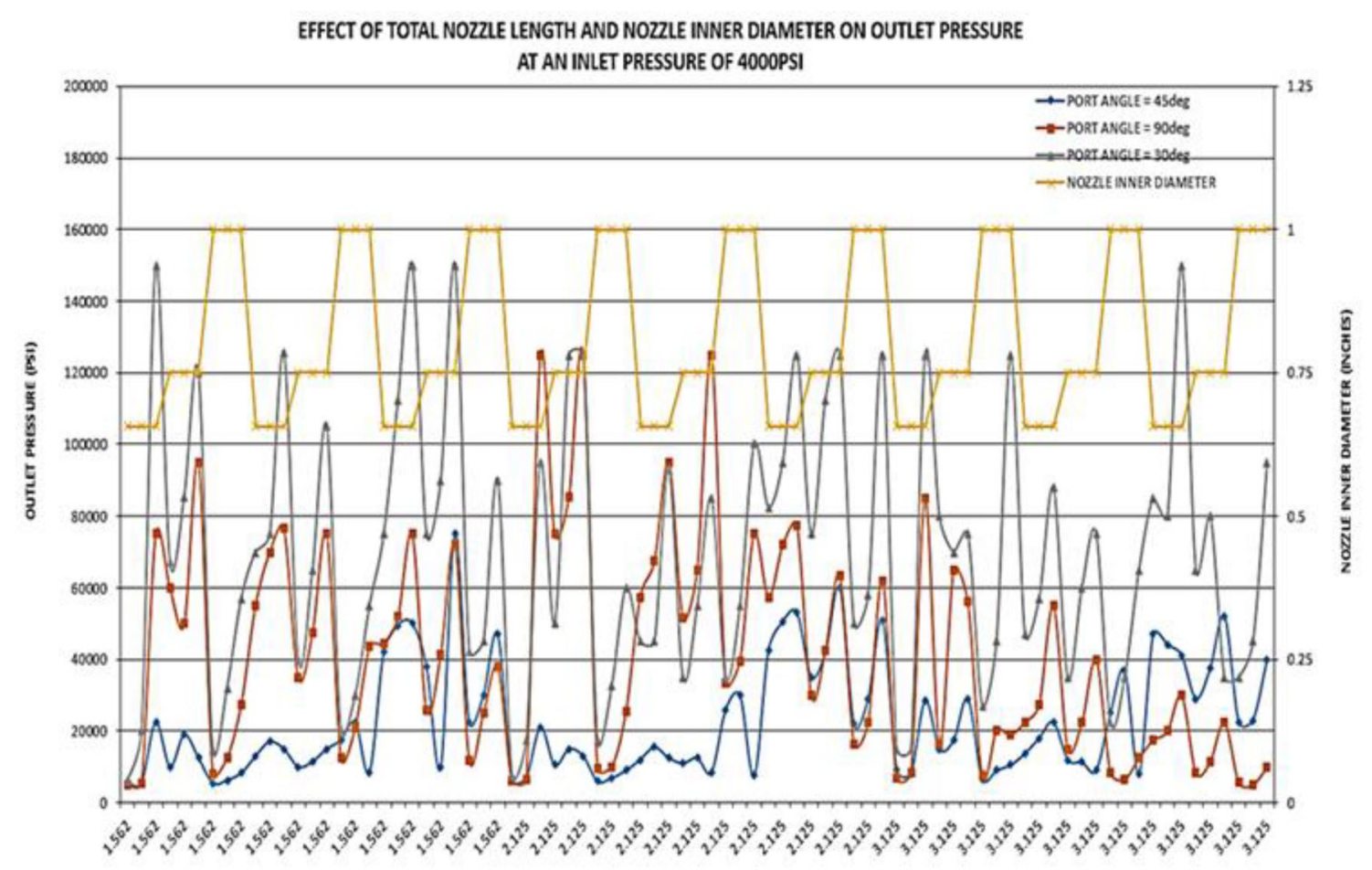

TOTAL NOZZE LENGTH (INCRES)

Fig. 11 Effect of total nozzle length and nozzle inner diameter on outlet pressure at an inlet pressure of 4000 PSI

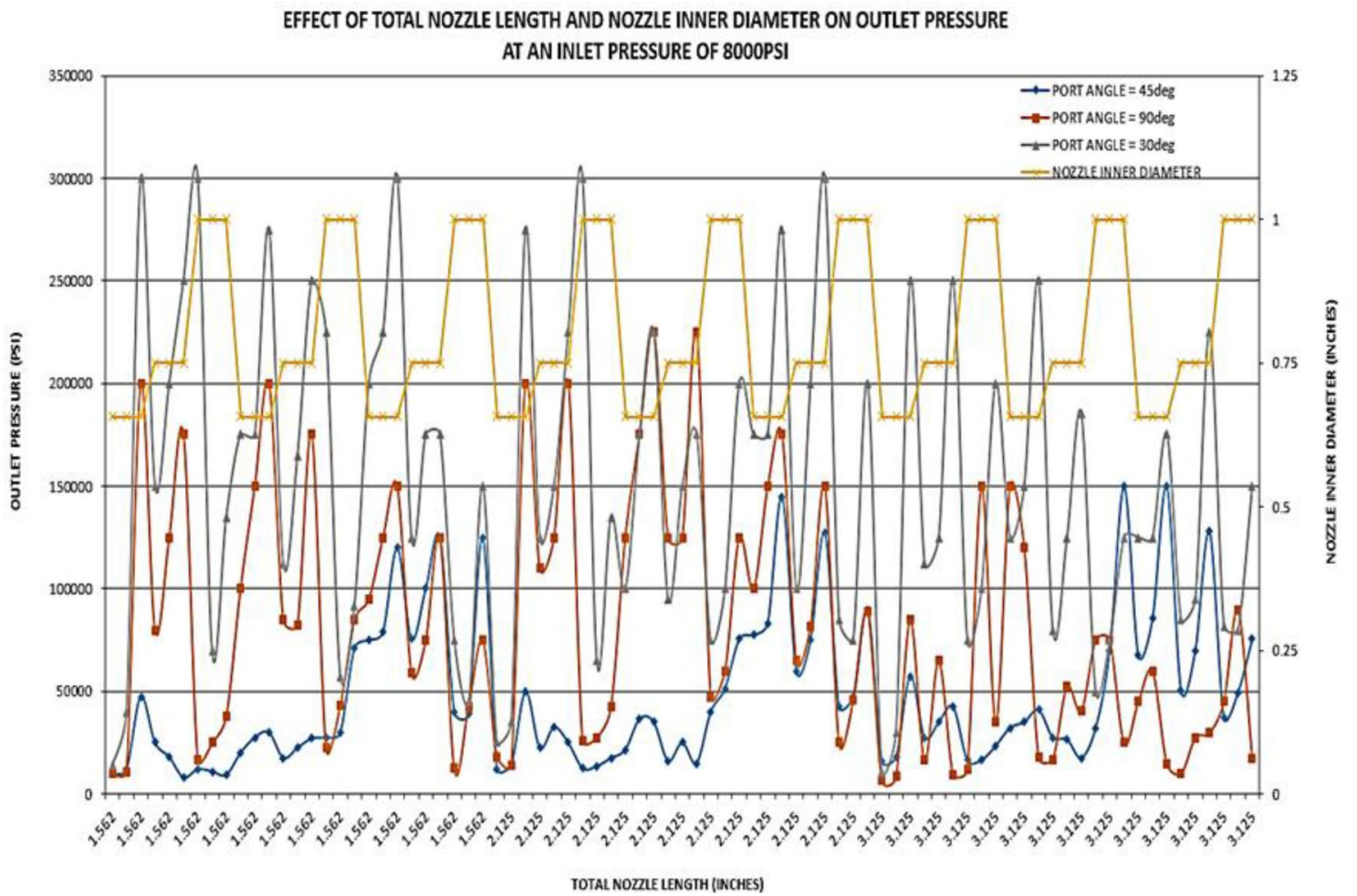

Fig. 12 Effect of total nozzle length and nozzle inner diameter on outlet pressure at an inlet pressure of 5000 PSI 
Table 8 Effects of total nozzle length, nozzle id and port angle on velocity

\begin{tabular}{llll}
\hline $\begin{array}{lll}\text { Factors effecting outlet } \\
\text { pressure }\end{array}$ & \multicolumn{2}{l}{ Effects on outlet pressure } & \\
\cline { 2 - 4 } & 4000 PSI & 5000 PSI & 8000 PSI \\
\hline Total nozzle length & $1.562^{\prime \prime}:$ High & $1.562^{\prime \prime}:$ High & $1.562^{\prime \prime}:$ High \\
& $2.125^{\prime \prime}:$ High & $2.125^{\prime \prime}:$ High & $2.125^{\prime \prime}$ High \\
& $3.125^{\prime \prime}:$ Low & $3.125^{\prime \prime}:$ Low & $3.125^{\prime \prime}$ Low \\
Nozzle id & $0.65^{\prime \prime}:$ High & $0.65^{\prime \prime}:$ High & $0.65^{\prime \prime}$ High \\
& $0.75^{\prime \prime}:$ Intermediate & $0.75^{\prime \prime}:$ Intermediate & $0.75^{\prime \prime}$ Intermediate \\
& $1^{\prime \prime}:$ Low & $1 ":$ Low & $1 "$ Low \\
Port angle & $30^{\circ}:$ High & $30^{\circ}:$ High & $30^{\circ}:$ High \\
& $45^{\circ}:$ Low & $45^{\circ}:$ Low & $45^{\circ}:$ Low \\
& $90^{\circ}:$ Intermediate & $90^{\circ}:$ Intermediate & $90^{\circ}:$ High \\
\hline
\end{tabular}

\section{Outlet velocity}

Figure 13 shows the outlet velocity of all the nozzle configurations (i.e.1port@0 $0^{\circ} 6$ ports@30 $0^{\circ}$, 1port@0 0 _4ports@90 and 1port@0 $0^{\circ}$ 4ports@45 ) with the total nozzle length (1.562 inch, 2.125 inch and 3.125 inch) on the $x$-axis, the outlet velocity on the $y$-axis, and the nozzle inner diameter on the secondary $y$-axis. The yellow-coloured line indicates the nozzle inner diameter ( 0.65 inch, 0.75 inch and 1 inch), and the grey, orange and blue plot lines differentiate between the different port angles, i.e. $30^{\circ}, 90^{\circ}$ and $45^{\circ}$. At an inlet pressure of 4000 PSI, nozzle length of 3.125 inch gives lower velocity as compared to nozzle length of 2.125 inch and 1.562 inch. Nozzle length of 3.125 inch gives a velocity in the range of $900-300 \mathrm{~m} / \mathrm{s}$. Nozzle length of 2.125 inch gives a cumulatively higher velocity at the outlet. Nozzle inner diameter of 1 inch does not deviate from the trend and gives low velocity rating, whereas ID of 0.65 inch and 0.75 inch gives high outlet velocity values in the range of 1100-400 m/s. The configuration1port@0 $0{ }^{\circ} 6$ ports@30 performs well followed by nozzles with $90^{\circ}$ port angles with values very close to the former. Nozzles with port angle of $45^{\circ}$ have outlet velocity in the range of 700-200 m/s. Figure 13 shows that a nozzle with port angle of $60^{\circ}$ with a total

EFFECT OF TOTAL NOZZLELENGTH AND NOZZLE INNER DIAMETER ON OUTLET VELOCTY AT AN INLET PRESSURE OF 4000PSI

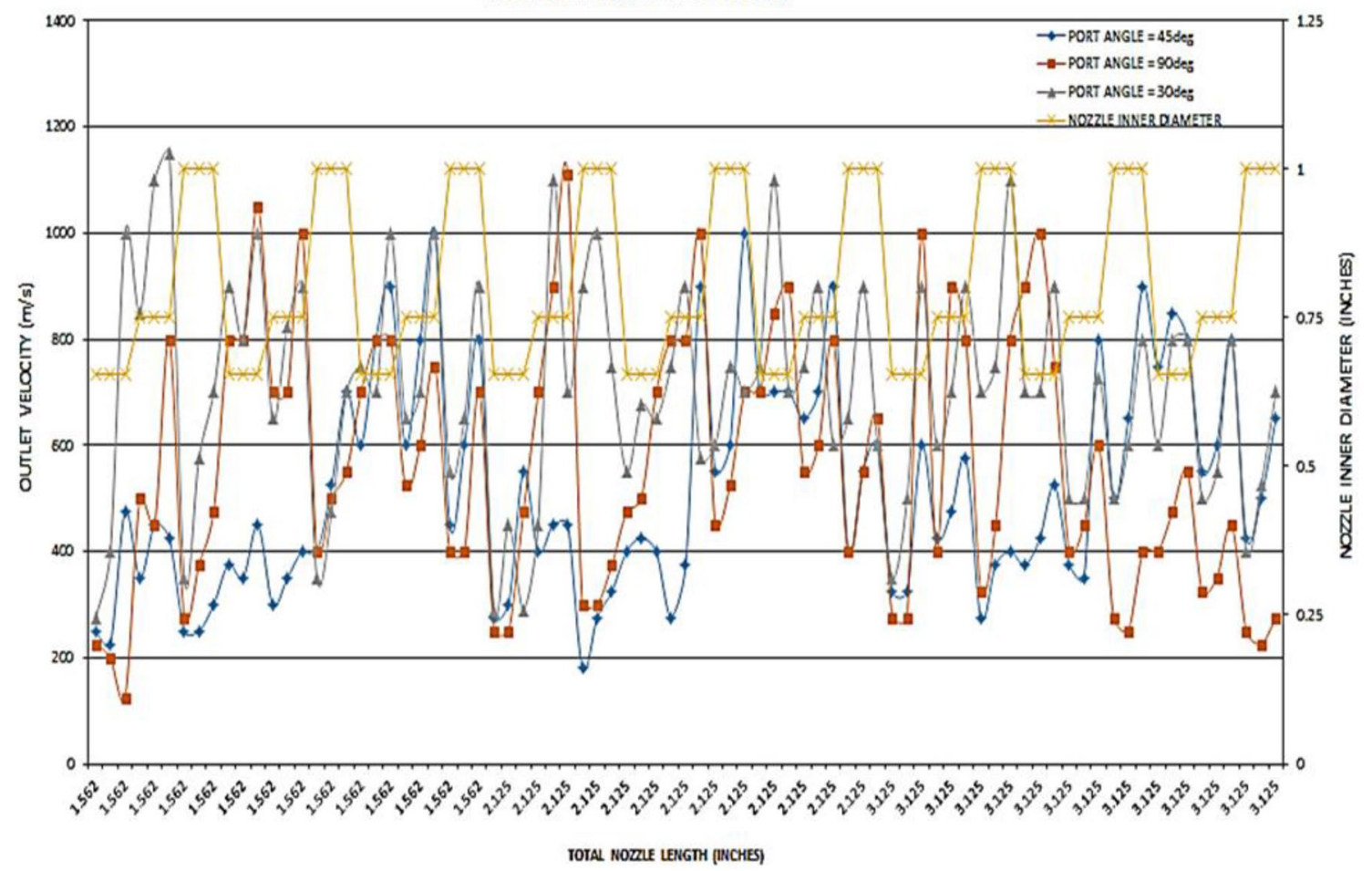

Fig. 13 Effect of total nozzle length and nozzle inner diameter on outlet velocity at an inlet pressure of 4000 PSI 
nozzle length of 2.125 inch along with a 0.65 -/0.75-inch nozzle ID would give the best possible performance.

Inlet pressure of 5000 PSI gives a more uniform outlet velocity as compared to the inlet pressure of 4000 PSI. The velocity lies in the range of $1100-300 \mathrm{~m} / \mathrm{s}$ for both inlet pressures as shown in Figs. 13 and 14. The highest velocities at the outlet are recorded with a total nozzle length of $2.125 \mathrm{inch}$, ranging from 1100 to $500 \mathrm{~m} / \mathrm{s}$. Nozzle length of 1.562 inch $(1100-300 \mathrm{~m} / \mathrm{s})$ and 3.125 inch $(1000-300 \mathrm{~m} / \mathrm{s})$ gives nearly the same outlet velocity values with 1.562 inch length being a bit higher. Nozzle inner diameter of 0.75 inch and 0.65 inch gives nearly the same high values of outlet velocity, with 0.75 inch giving a bit higher outlet velocity value. Nozzle length of 1 inch creates a sudden dip in the recorded outlet velocity values as can be seen from the plot. Again, nozzles with1port@0﹎6ports@30․ configuration perform well followed by 1port@0 $0^{\circ} 4$ ports@90 $90^{\circ}$ nozzle configuration. The nozzles with port angle of $45^{\circ}$ perform better than before but, on an average, give lower velocities at the outlet. The best performing nozzle in this case would be a nozzle with a port angle of $30^{\circ}$ with 2.125 inch nozzle length and a 0.65 inch or 0.75 inch nozzle inner diameter.

The performance of nozzles with $45^{\circ}$ port angle increases with increase in inlet pressure from 5000 PSI to 8000 PSI as shown in Figs. 14 and 15. In totality, the best outlet velocities resulted from nozzles with a port angle of $30^{\circ}$, but $90^{\circ}$ port angle nozzles were close. The middle nozzle length of 2.125 inch achieves the highest outlet velocities in the range of $1400-400 \mathrm{~m} / \mathrm{s}$, followed by nozzle length of 1.562 inch giving outlet velocities in the range of $1300-300 \mathrm{~m} / \mathrm{s}$. Lower outlet velocities in between 1200 and $300 \mathrm{~m} / \mathrm{s}$ are achieved by nozzles with a total nozzle length of 3.125 inch. Nozzle inner diameter of 1 inch lowers the outlet velocities drastically, whereas 0.65 -inch nozzle ID and 0.75 -inch nozzle ID give consistently higher outlet velocities. Nozzles with port diameter of $30^{\circ}$ perform exceedingly well, followed closely by $90^{\circ}$ port angle nozzles. Therefore, a nozzle with a $60^{\circ}$ port angle having a 2.125 inch nozzle length with a nozzle inner diameter of 0.75 inch or 0.65 inch gives exceptionally well performance. Table 9 shows the evaluation of various combinations of design for obtaining the required outlet velocity by varying total nozzle length, nozzle ID and port angle at $4000-8000$ psi pump pressure.

\section{Nozzle selection}

After examining all the simulation results, it is clear that nozzles with a port angle of $30^{\circ}$ achieve the best performance. Therefore, selecting an appropriate nozzle for sand removal is done by selecting all the parameters which have

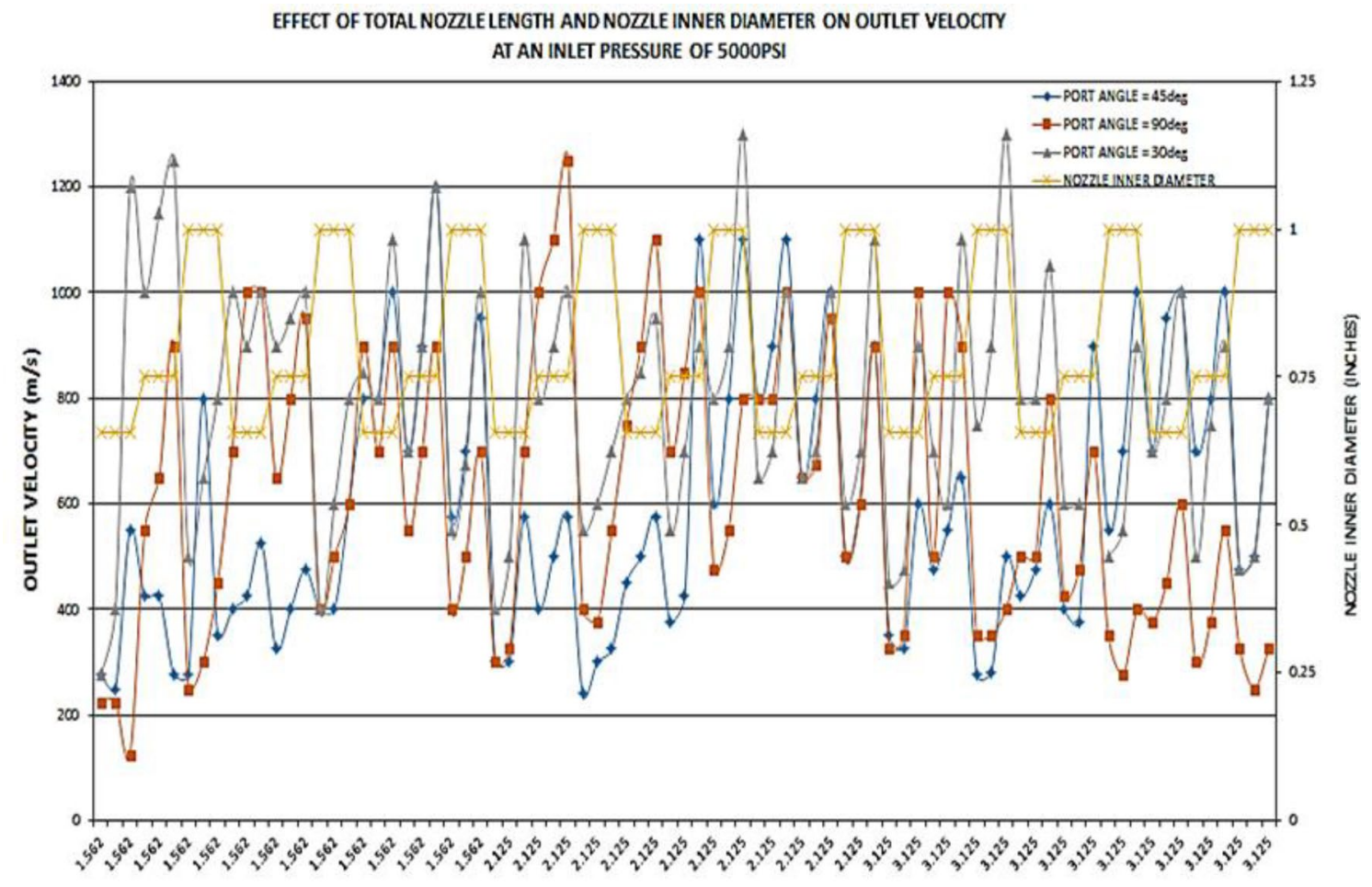

TOTAL NOZLE LENGTH (INCHES)

Fig. 14 Effect of total nozzle length and nozzle inner diameter on outlet velocity at an inlet pressure of 5000 PSI 
EFFECT OF TOTAL NOZZIELENGTH AND NOZZLE INNER DIAMETER ON OUTLET VELOCTYY AT AN INLET PRESSURE OF 8000PSI

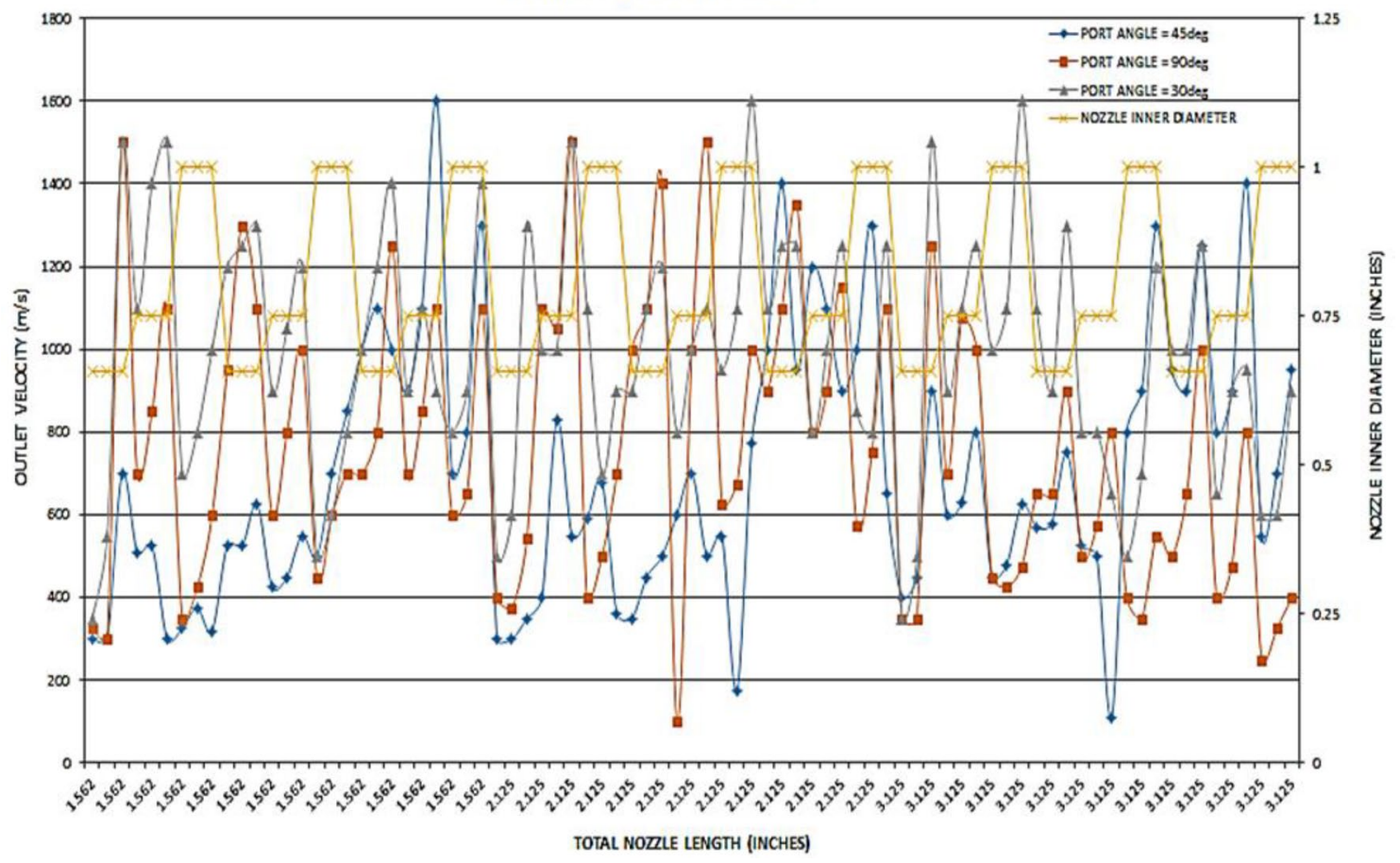

Fig. 15 Effect of total nozzle length and nozzle inner diameter on outlet velocity at an inlet pressure of 8000 PSI

Table 9 Effects of total nozzle length, nozzle id and port angle on outlet velocity

\begin{tabular}{llll}
\hline $\begin{array}{l}\text { Factors effecting outlet } \\
\text { velocity }\end{array}$ & \multicolumn{2}{l}{ Effects on outlet velocity } & \\
\cline { 2 - 4 } & 4000 PSI & 5000 PSI & 8000 PSI \\
\hline Total nozzle length & $1.562^{\prime \prime}:$ High & $1.562^{\prime \prime}:$ Intermediate & $1.562^{\prime \prime}$ Intermediate \\
& $2.125^{\prime \prime}:$ High & $2.125^{\prime \prime}:$ High & $2.125^{\prime \prime}:$ High \\
& $3.125^{\prime \prime}:$ Low & $3.125^{\prime \prime}:$ Low & $3.125^{\prime \prime}:$ Low \\
Nozzle id & $0.65^{\prime \prime}:$ High & $0.65^{\prime \prime}:$ High & $0.65^{\prime \prime}:$ High \\
& $0.75^{\prime \prime}:$ High & $0.75^{\prime \prime}:$ High & $0.75^{\prime \prime}:$ High \\
& $1^{\prime \prime}:$ Low & $1 ":$ Low & $1 ":$ Low \\
Port angle & $30^{\circ}:$ High & $30^{\circ}:$ High & $30^{\circ}:$ High \\
& $45^{\circ}:$ Low & $45^{\circ}:$ Low & $45^{\circ}:$ Intermediate \\
& $90^{\circ}:$ Intermediate & $90^{\circ}:$ High & $90^{\circ}:$ High \\
\hline
\end{tabular}

recorded high outlet velocity, flow rate and pressure values for the 1port@0 $0^{\circ}$ 6ports@30․ configuration, while in the case of nozzle for scale removal nozzles with port angle of $90^{\circ}$ give the second-best performance as shown in Table 10. It gives high values to intermediate pressure, velocity and mass flow rate at output. The selections made in the previous section for the $30^{\circ}$ port angle nozzle give optimum performance for $90^{\circ}$ port angle.

The optimized dimensions of coiled tubing jetting nozzle parameters for sand transport from wellbore are as follows;

i. Port diameter To get a high outlet pressure and mass flow rate, 0.155 inch port diameters should be used, whereas high velocity is achieved by the smaller 0.09 inch port diameter. Therefore, it can be concluded that, to achieve high pressure and rate, a higher port diameter should be used. On the other hand, a smaller port diameter creates higher velocity at the outlet.

ii. Cone angle The larger cone angle of $45^{\circ}$ gives a higher value of the outlet pressure, flow rate and velocity. Therefore, during selection the higher the cone angles the better the results.

iii. Total nozzle length The medium nozzle length of 2.125 inch has given consistently high results at the outlet, followed closely by the smaller 1.562 -inch-long nozzles. Hence, the performance of a nozzle reduces 
Table 10 Selection of nozzle for sand and scale removal

\begin{tabular}{|c|c|c|c|c|c|c|}
\hline \multirow[t]{2}{*}{ Function } & \multicolumn{5}{|c|}{ Dimensional characteristics } & \multirow{2}{*}{$\begin{array}{l}\text { Performance character- } \\
\text { istics } \\
\{\text { Pressure (PSI) velocity } \\
(\mathrm{M} / \mathrm{S}) \text { flow rate (GPM) }\}\end{array}$} \\
\hline & Port angle & $\begin{array}{l}\text { Port diameter } \\
\text { (Inch) }\end{array}$ & Cone angle & $\begin{array}{l}\text { Nozzle length } \\
\text { (Inch) }\end{array}$ & $\begin{array}{l}\text { Nozzle ID } \\
\text { (Inch) }\end{array}$ & \\
\hline Sand removal & $30^{\circ}$ & 0.155 & $45^{\circ}$ & 2.125 & $0.65 / 0.75$ & $\begin{array}{l}150,000-30,000 \\
1200-400 \\
250-50\end{array}$ \\
\hline Scale removal & $90^{\circ}$ & 0.155 & $45^{\circ}$ & 2.125 & $0.65 / 0.75$ & $\begin{array}{l}100,000-10,000 \\
900-200 \\
150-20\end{array}$ \\
\hline
\end{tabular}

with an increase in the nozzle length and also when the length is too short.

iv. Nozzle inner diameter The smaller nozzle inner diameters of 0.65 inch and 0.75 inch have performed equally well, and the 1-inch ID has given low performance. Therefore, the lower the nozzle diameter, the better the performance.

\section{Conclusion}

The design optimization of nozzle has shown enhanced outcomes. The velocity required to clean the different types of scales and sand is between 100 and $600 \mathrm{~m} / \mathrm{s}$. The results of this project give an outlet velocity in the range of 100-1200 m/s, which clearly proclaims that these designs can be efficiently used to remove all the substances retarding production. For high outlet pressure and mass flow rate, port of 0.155 inch diameters should be used, while the highest velocity is achieved with the smaller port of 0.09 inch diameter. Therefore, it can be deduced that to obtain a higher pressure and a higher flow rate, it is necessary to use a larger diameter of port. On the other hand, a smaller port diameter creates higher velocity at the outlet.

Acknowledgements The authors would like to thank the Institute of Hydrocarbon Recovery, Universiti Teknologi PETRONAS, for the financial assistance and computational support to complete this work.

Open Access This article is distributed under the terms of the Creative Commons Attribution 4.0 International License (http://creativeco mmons.org/licenses/by/4.0/), which permits unrestricted use, distribution, and reproduction in any medium, provided you give appropriate credit to the original author(s) and the source, provide a link to the Creative Commons license, and indicate if changes were made.

\section{References}

Afghoul A, Amaravadi S, Boumali A, Calmeto J, Lima J, Lovell J, Tinkham S, Zemlak K, Staal T (1994) Coiled tubing: the next generation. Oilfield Rev 6(4):9-23
Ali A, Blount CG, Hill S, Pokhriyal J, Weng X, Loveland MJ, Mokhtar S, Pedota J, Rødsjø M, Rolovic R, Zhou W (2004) Integrated wellbore cleanout systems: improving efficiency and reducing risk. Oilfield Rev 16(1):38-57

Connell ML, Courville P and Tucker J (2000) Coiled tubing-deployed jetting tool enhances cleaning and jet cutting. In: SPE/ICoTA coiled tubing roundtable

Connell M, Courville P, Tucker J (2000) A coiled tubing-deployed slow-rotating jet cleaning tool enhances cleaning and allows jet cutting of tubulars. In: SPE permian basin oil and gas recovery conference

Deng F, Deng J, Yan W, Zhu H, Huang L, Chen Z (2013) The influence of fine particles composition on optimal design of sand control in offshore oilfield. J Pet Explor Prod Technol 3(2):111-118

Gardner Denver (2018) www.gardnerdenver.com/en/gdproducts

Khan JA, Pao WK (2013) Removal with foam in horizontal well cleaning in coiled tubing. Res J Appl Sci Eng Technol 6(14):2655-2661

Li J, Green T (2011) Coiled tubing sand clean outs utilizing BHA technology and simulation software in demanding wellbore geometries. In: SPE/DGS Saudi Arabia Section technical symposium and exhibition

Li J, Luft BH, Wilde G, Alingig G, Jumawid F (2008) Cleanouts with coiled tubing in low-bottom hole-pressure wellbores. In: SPE/ICoTA coiled tubing and well intervention conference and exhibition

Li J, Misselbrook J, Sach M (2010) Sand cleanouts with coiled tubing: choice of process, tools and fluids. J Can Pet Technol 49(08):69-82

Mohamad-Hussein A, Ni Q (2018) Numerical modelling of onset and rate of sand production in perforated wells. J Pet Explor Prod Technol 8(4):1255-1271

Pao WK, Khan JA (2014) Horizontal well clean-up operation using foam in different coiled tubing/annulus diameter ratios. J Appl Sci 14:3235-3241

Pao W, Khan JA, Ofei TN, Irawan S (2015) Fill removal from horizontal wellbore using foam in different coiled tubing/annulus diameter ratios. Int J Oil Gas Coal Technol 9(2):129-147

Piroozian A, Ismail I, Yaacob Z, Babakhani P, Ismail ASI (2012) Impact of drilling fluid viscosity, velocity and hole inclination on cuttings transport in horizontal and highly deviated wells. J Pet Explor Prod Technol 2(3):149-156

Zakerian A, Sarafraz S, Tabzar A, Hemmati N, Shadizadeh SR (2018) Numerical modelling and simulation of drilling cutting transport in horizontal wells. J Pet Explor Prod Technol 8(2):455-474

Publisher's Note Springer Nature remains neutral with regard to jurisdictional claims in published maps and institutional affiliations. 